Pesq. Vet. Bras. 36(12):1178-1180, dezembro 2016

DOI: $10.1590 / \mathrm{S} 0100-736 \mathrm{X} 2016001200006$

\title{
Prevalence and in vitro susceptibility of methicillin-resistant Staphylococcus pseudintermedius (MRSP) from skin and nostrils of dogs with superficial pyoderma ${ }^{1}$
}

\author{
Larissa S. Botoni ${ }^{2}$, Carolina B. Scherer ${ }^{2}$, Rodrigo O. Silva ${ }^{3}$, Fernanda M. Coura ${ }^{3}$, \\ Marcos B. Heinemann ${ }^{4}$, Fabiola O. Paes-Leme ${ }^{2}$ and Adriane P. Costa-Val ${ }^{2 *}$
}

\begin{abstract}
Botoni L.S., Scherer C.B., Silva R.O., Coura F.M., Heinemann M.B., Paes-Leme F.O. \& Costa-Val A.P. 2016. Prevalence and in vitro susceptibility of methicillin-resistant Staphylococcus pseudintermedius (MRSP) from skin and nostrils of dogs with superficial pyoderma. Pesquisa Veterinária Brasileira 36(12):1178-1180. Departamento de Clínica e Cirurgia, Escola de Veterinária, Universidade Federal de Minas Gerais, Av. Antonio Carlos 6627, Cx. Postal 567, Belo Horizonte, MG 31270-010, Brazil. E-mail: adriane@ufmg.br

In order to assess the prevalence of Methicillin-resistant Staphylococcus pseudintermedius from skin and nostrils of dogs with pyoderma, to determine its in vitro susceptibility, and to correlate these data with the presence of the mecA gene, 43 dogs were selected. Samples were collected from secretion of their skin lesions and right nostril, cultured, and analyzed for phenotypic and genotypic characteristics of the bacteria studied. In 62 samples (91\%) the microorganism was classified as S. pseudintermedius. The rate of resistance against antibiotics ranged from 7\% (amikacin; 4/62) to 77\% (sulfamethoxazole + trimethoprim; 48/62). Resistance against oxacillin was found in $34 \%$ of the samples $(21 / 62)$. Twenty-five samples (37\%) were strains that carried the mecA gene. A significant correlation $(\mathrm{P}<0.01)$ was found between presence of the mecA gene and oxacillin resistance. Seventeen dogs were mecA gene carriers, and $8(47 \%)$ of them had the gene in the skin lesions and nostril. A significant correlation $(\mathrm{P}<0.01)$ was also observed between the presence of mecA gene in the skin lesions and nostrils. Oxacillin resistance in vitro can be safely used to indicate the presence of mecA gene in MRSP samples. The nostrils can be a reservoir of MRSP in dogs.
\end{abstract}

INDEX TERMS: Skin disease, Staphylococcus pseudintermedius, staphylococcal infections, antibiotics, oxacillin, mecA, MRSP, dogs.

RESUMO.- [Prevalência e suscetibilidade in vitro de Staphylococcus pseudintermedius resistente à meticilina (MRSP) oriundos de pele e narinas de cães com piodermite superficial.] Para acessar a prevalência de MRSP

\footnotetext{
${ }^{1}$ Received on June 17, 2015.

Accepted for publication on April 13, 2016.

${ }^{2}$ Departamento de Clínica e Cirurgia, Escola de Veterinária, Universidade Federal de Minas Gerais (UFMG), Av. Antonio Carlos 6627, Cx. Postal 567, Belo Horizonte, MG 31270-010, Brazil. *Corresponding author: adriane@ufmg.br

${ }^{3}$ Departamento de Medicina Veterinária Preventiva, Escola de Veterinária, UFMG, Av. Antonio Carlos 6627, Cx. Postal 567, Belo Horizonte, MG 31270-010, Brazil.

${ }^{4}$ Departamento de Medicina Veterinária Preventiva e Saúde Animal, Faculdade de Medicina Veterinária e Zootecnia (FMVZ), Universidade de São Paulo (USP), Av. Prof. Dr. Orlando Marques de Paiva 87, Cidade Universitária, São Paulo, SP 05508-270, Brazil.
}

na pele e nas narinas de cães com piodermite superficial, determinar a suscetibilidade in vitro, e correlacionar estes dados com a presença do gene $m e c A$, foram selecionados 43 cães. Amostras de lesões de pele e narinas foram coletadas, cultivadas, e analisadas fenotipica e genotipicamente. Em 62 amostras (91\%), os microrganismos foram classificados como Staphylococcus pseudintermedius. A taxa de resistência a antibióticos variou entre 7\% (amicacina; 4/62) e 77\% (sulfamethoxazol + trimetoprim; 48/62). Resistência a oxacilina foi observada em $34 \%$ das amostras (21/62). Vinte e cinco amostras (37\%), eram cepas portadoras do gene $m e c A$. Correlação significativa $(\mathrm{P}<0,01)$ foi observada entre a presença do gene $m e c A$ e a resistência à oxacilina. Considerando os cães, 17 eram portadores de cepas com gene mecA e $8(47 \%)$ delas carreavam este gene nas amostras de lesão de pele e nas narinas. Correlação significativa $(\mathrm{P}>0,01)$ foi 
observada entre a presença do gene mecA nas lesões de pele e nas narinas. Sendo assim, resistência à oxacilina in vitro pode ser aferida com segurança para indicar a presença do gene mecA em amostras de MRSP, e as narinas podem constituir em um reservatório dos microorganismos em cães.

TERMOS DE INDEXAÇÃO: Doença de pele, Staphylococcus pseudintermedius, infecções estafilocócicas, antibióticos, oxacilina, mecA, MRSP, caninos.

\section{INTRODUCTION}

Superficial pyoderma is one of the most frequent dermatopathies in dogs. This disease is an infection of epidermis and hair follicles. The main clinical signs include circular alopecia, erythema, pustules, epidermal collarettes, crusts, desquamation, and pruritus. Most cases are due to a primary cause, and allergy, demodicosis, endocrinopathy, and dekeratinization are the most frequent (Miller et al. 2013).

These bacteria were previously classified as Staphylococcus intermedius. However, Devriese et al. 2005 using molecular characterization in samples from canine, fox, and pigeon, found three different species among those known as $S$. intermedius. Those three species, S. pseudintermedius, $S$. intermedius, and S. delphini, compose the $S$. intermedius Group (SIG) (Devriese et al. 2005, Bannoehr \& Guardabassi 2012, Miller et al. 2013).

In the past, the Staphylococcus genus was known to be sensitive to beta-lactamic drugs. However, in the last three decades the prevalence of strains resistant to those drugs has increased (Weese \& Van Duijkeren 2010, Beck et al. 2012) This is a notorious problem in veterinary dermatology, since beta-lactamic antibiotics are the first choice option in the treatment of bacterial pyoderma (Miller et al. 2013). Such resistant strains are called methicillin-resistant Staphylococcus pseudintermedius (MRSP) (Weese \& Van Duijkeren 2010). The MRSP strains carry the mecA gene, which encodes an altered penicillin-binding protein known as PBP2a, which reduces the bacterial affinity to all beta-lactamic antibiotics (Weese \& Van Duijkeren 2010, Wang et al. 2012).

Despite the importance of MRSP strains, few studies focusing on their prevalence, antibiotic susceptibility, and presence of the $M e c A$ gene and/or correlating these variables to oxacillin resistance in dogs with pyoderma are found in the literature. Therefore, the objectives of this study were to determine the prevalence of MRSP from skin lesions and nostrils, determine their in vitro susceptibility, and correlate MRSP occurrence in both sites.

\section{MATERIALS AND METHODS}

Dogs. Samples were obtained from 43 dogs presented to a referral service in Belo Horizonte (MG, Brazil), where they were diagnosed with superficial pyoderma by the clinical presentation and cytological smears. Presence of typical pyoderma lesions, such as papules, pustules, collarettes, and erythema, were the clinical criteria. Cytological smears should present at least five coccoid bacteria per immersion oil field, as well as inflammatory cells. The project was approved by the Ethical Committee for Animal Use of Universidade Federal de Minas Gerais.

Sample collection and processing. Two sterile cotton swabs were utilized to collect the samples, one from the right nostril and the other from the skin lesion, which were immediately inoculated into the Stuart transport media. Within $48 \mathrm{~h}$, the samples were inoculated into sheep blood agar $(5 \%)$ and incubated $\left(37^{\circ} \mathrm{C} ; 24 \mathrm{~h}\right)$. After incubation, the small, creamy colonies were selected. Smears were done from these colonies and then stained with Gram stain. The Gram-positive coccoid bacteria samples were selected and re-cultured in Mueller-Hinton agar.

Identification of isolates. For differentiation among specimens of the genus Staphylococcus and other Gram-positive coccoid bacteria, evaluation of the colony morphology and phenotypic tests such as coagulase test, and catalase and oxidase reactions were performed. After classification as Staphylococcus sp., Voges-Proskauer, fermentation of carbohydrates (mannitol, sucrose, and trehalose), urease production, and polymyxin B sensitivity tests were performed to differentiate SIG from other species. After isolation, all coccoid bacteria samples were identified using molecular methods, with specific primers for S. pseudintermedius, as previously described (Sasaki et al. 2010).

Susceptibility tests and genotypic identification. After phenotypic identification, the samples were inoculated into Mueller-Hinton agar with antibiotic discs impregnated with amikacin $(30 \mu \mathrm{g})$, amoxicillin + clavulanate $(20 / 10 \mu \mathrm{g})$, cephalexin $(30 \mu \mathrm{g})$, gentamycin $(10 \mu \mathrm{g})$, chloramphenicol $(30 \mu \mathrm{g})$, streptomycin $(30 \mu \mathrm{g})$, enrofloxacin $(5 \mu \mathrm{g})$, oxacillin $(1 \mu \mathrm{g})$, penicillin $(10 \mu \mathrm{g})$, tetracycline $(30 \mu \mathrm{g})$, and sulfamethoxazole + trimethoprim $\left(1.25 / 23.75 \mu \mathrm{g} ; \mathrm{DME}^{\circledR}\right.$, Araçatuba, SP, Brazil) following the CLSI (Clinical and Laboratory Standards Institute) recommendations for Staphylococcus sp. susceptibility tests. The mecA gene was genotypically identified as described elsewhere (Mehrotra et al. 2000).

Statistical analysis. The statistical analysis was performed based on frequency and Spearman's correlation test.

\section{RESULTS}

\section{Identification of isolates}

From all samples collected, 68 isolates were recovered; $88.2 \%$ of them were classified as SIG by using the phenotypic tests, and $91 \%$ of the samples were classified as Staphylococcus pseudintermedius using the genotypic tests. From the samples recovered (68), 42 were from the skin lesions and 26 from the nostrils. Regarding the genotypic tests, $88 \%(37 / 42)$ of samples from skin lesions were classified as S. pseudintermedius, whereas $96 \%(25 / 26)$ of those from the nostrils were classified as so.

\section{Susceptibility tests}

Susceptibility to the drugs tested was variable, as only $10 \%$ of the dogs were shown to have bacteria strains susceptible to all drugs, 28\% exhibited patterns of resistance to six or more drugs, and none had strains resistant to all antibiotics. Amikacin (93\%) and chloramphenicol (82\%) were the most efficient drugs in terms of susceptibility in vitro. Drug resistance to amoxicillin + clavulanate and cephalexin $(23 \%$ and $24 \%$, respectively) and oxacillin (34\%) was observed, being quite similar to each other.

\section{Identification of the mecA gene}

The isolates were tested for the mecA gene and $37 \%$ $(25 / 68)$ were shown to carry the gene. Thus, significant correlation $(P<0,01, \mathrm{R}=0,0004)$ was found between presence of the mecA gene (37\%) and oxacillin resistance (34\%). Regarding the mecA-positive samples, $48 \%(12 / 25)$ 
of them were from skin lesion samples and 52\% (13/25) were from nostrils, and 35,4\%(17/43) of all dogs were shown to carry the gene. Prevalence of mecA gene among skin lesions $(28.5 \%)$ and nostrils (50\%) was also calculated. From the 17 dogs that were $m e c A$ gene carriers, 8 (47\%) had the gene in both skin lesions and nostril. A significant correlation $(P<0,01, \mathrm{R}=0,002)$ was also observed between the presence of $m e c A$ gene in the skin lesions and nostrils.

\section{DISCUSSION}

In this study, we found 91\% prevalence for Staphylococcus pseudintermedius, which was higher than that found by other authors (Paul et al. 2012). They found 69\% of this species among their samples, which were collected from the oral cavity, perianal region, and nostrils of healthy animals. Therefore, the prevalence might be lower in that study due to the absence of pyoderma (healthy animals). On the other hand, similar prevalences were found in China (92\%) (Wang et al. 2012) and Brazil (96\%) (Bourguignon 2012). Both brazilian and chinese groups used samples from animals with pyoderma, thus reinforcing the idea that presence of the disease increases the presence $S$. pseudintermedius.

Regarding the drugs used in the susceptibility tests, the highest values were found for amikacin and chloramphenicol. However, these drugs are known for their considerable side effects, which narrow their routine use. Amikacin is not available for oral use, and its main side effect is nephrotoxicity, thus requiring that the patient be very carefully monitored Chloramphenicol is known to cause bone marrow aplasia, being forbidden for human use in Brazil. Consequently, it is not available for retail in drugstores in this country (Andrade 2002). Our results for these drugs are in agreement with those found in the literature (Onuma et al. 2012). Our resistance rates for cephalexin and amoxicillin + clavulanate differ from those found in other studies (Bourguignon 2012, Onuma et al. 2012) in which the authors found lower (ca. 15\%) resistance rates for these drugs. All these studies were conducted in different locations and the resistance rates may vary among regions due to different use of antibiotics.

Within the samples, prevalence of the mecA gene was $37 \%$ and it showed a positive correlation $(P<0,01 ; \mathrm{R}=0,0004)$ with resistance to oxacillin (34\%). Therefore, both tests can be used safely to determine methicillin resistance in dogs. These results are in agreement with those found in the USA (Bemis et al. 2006) However, such results differ from those obtained in Brazil (Bourguignon 2012), which did not show to have positive correlation between the tests.

Regarding presence of the mecA gene in the skin lesions and nostril, a positive Spearman's correlation $(P<0,01$; $\mathrm{R}=0,002$ ) between the locations was obtained in the present study. Beck et al. 2012 also observed a positive correlation between their samples from skin and nostrils, as used in the present study. Therefore, these data indicate that the nostrils could be a reservoir of MRSP in skin infections (Beck et al. 2012).

\section{CONCLUSIONS}

Staphylococcus pseudintermedius was the most frequent bacteria among the samples from dogs with superficial pyoderma.

The nostrils of affected dogs represent a possible reservoir of $S$. pseudintermedius for skin infection.

Both methods, oxacillin resistance and $m e c A$ gene presence, can be used to determine the colonization by MRSP in dogs with superficial pyoderma.

Acknowledgements.- This study was financially supported Fundação de Amparao a Pesquisa de Minas Gerais Staphylococcus pseudintermedius (FAPEMIG). The authors are grateful to Gustavo Drumond Pawlowski for his excellent technical assistance. MBH is grateful to CNPq for the fellowships.

\section{REFERENCES}

Andrade S.F. 2002 . Manual de Terapêutica Veterinária. Roca, São Paulo.

Bannoehr J. \& Guardabassi L. 2012. Staphylococcus pseudintermedius in the dog: taxonomy, diagnostics, ecology, epidemiology and pathogenicity. Vet. Dermatol. 23(4):253-266.

Beck K.M., Waisglass S.E., Dick H.L.N. \& Weese J.S. 2012. Prevalence of Meticillin-Resistant Staphylococcus pseudintermedius (MRSP) from skin and carriage sites of dogs after treatment of their meticillin-resistant or meticillin-sensitive staphylococcal pyoderma. Vet. Dermatol. 23(4):1821.

Bemis D.A., Jones R.D., Hiatt L.E., Ofori E.D., Rohrbach B.W., Frank L.A. \& Kania S.A. 2006. Comparison of tests to detect oxacillin resistance in Staphylococcus intermedius, Staphylococcus schleiferi, and Staphylococcus aureus isolates from canine hosts. J. Clin. Microbiol. 44(9):3374-3376.

Bourguignon E. 2012 Identificação e perfil de resistência a antimicrobianos de Staphylococcus pseudinterm e A. dius isolados de piodermite canina. UFV, Viçosa.

Devriese L.A., Vancanneyt M., Baele M., Vaneechoutte M., De Graef E., Snauwaert C., Cleenwerck I., Dawyndt P., Swings J., Decostere A. \& Haesebrouck F. 2005. Staphylococcus pseudintermedius sp. nov., a coagulase-positive species from animals. Int. J. Syst. Evol. Microbiol. 55(4):15691573.

Mehrotra M., Wang G. \& Johnson W.M. 2000. Multiplex PCR for detection of genes for Staphylococcus aureus enterotoxins, exfoliative toxins, toxic shock syndrome toxin 1, and methicillin resistance. J. Clin. Microbiol. 38(3):1032-1035

Miller W.H., Griffin C.E. \& Campbell K.L. 2013. Small Animal Dermatology. Elsevier, St Louis, Missouri.

Onuma K., Tanabe T. \& Sato H. 2012. Antimicrobial resistance of Staphylococcus pseudintermedius isolates from healthy dogs and dogs affected with pyoderma in Japan. Vet. Dermatol. 23(1):17-23.

Paul N.C., Bärgman S.C., Moodley A., Nielsen S.S. \& Guardabassi L. 2012. Staphylococcus pseudintermedius colonization patterns and strain diversity in healthy dogs: a cross-sectional and longitudinal study. Vet. Microbiol. 160(3/4): 420-427.

Sasaki T., Tsubakishita S., Tanaka Y., Sakusabe A., Ohtsuka M., Hirotaki S., Kawakami T., Fukata T. \& Hiramatsu K. 2010. Multiplex-PCR method for species identification of coagulase-positive staphylococci. J. Clin. Microbiol. 48(3):765-769.

Wang Y., Yang J., Logue C.M., Liu K., Cao X., Zhang W., Shen J. \& Wu C. 2012. Methicillin-resistant Staphylococcus pseudintermedius isolated from canine pyoderma in North China. J. Appl. Microbiol. 112(4):623-630.

Weese J.S. \& Van Duijkeren E. 2010. Methicillin-resistant Staphylococcus aureus and Staphylococcus pseudintermedius in veterinary medicine. Vet. Microbiol. 140(3/4):418-429. 